\title{
$P 115$
}

\section{職場の冷房環境と低出生体重児のコホート研究}

○徳井教孝 1 、新小田春美 2 、吉村健清 1

1 .産医大臨床疫学、2.産医大保健学部

【目的】母親の瞕業と低出生体重児との関連は、これまで多くの疫学研究により報告されてい る。しかし、勤労女性の職場環境と低出生体重児との関連を研究した報告は少ない。日本では 夏期に冷房により勤労女性の冷え症等の訴えが多いことが指摘されている。このような職場環 境で妊婦が勤務する場合、胎児の健康状態に影響する可能性が考えられる。そこで、妊娠初期 から妊婦を追跡し、冷房環境亡低出生体重児との関連を検討した。

【対象と方法】1994 年 2 月から1996 年12月までに、5つの病院を受診した妊婦につ いて調査協力の依頼を行った。承諾の得られた妊婦 840 名について、妊娠 16 週、2 2 週、 30 週に健康調査を行い、生活習慣、職場環境、ストレス等を調査した。冷房環境について は、冷房環境に問題があると回答した勤労女性と問題ないと回答した勤労女性の 2 群に分類し た。出生体重のデータはカルテから収集した。今回の低出生体重児の定義は、出生体重が $2500 \mathrm{~g}$ 末満である。解析は、初産婦、経産婦に分けて、16週、2 2 週の時の冷房環境と 低出生体重児との関連をロジステイックモデルを用いてオッズ比を算出した。その際、交絡因 子として、年路、身長、在胎週数を用いた。

【結果、及び考察】低出生体重児の発生率は、初産婦では、専業主婦が7.7\%、勤労女性が9.1 \%、程産婦では、専業主婦で6.7\%、勤労女性で3.7\%であった。冷房環境亡低出生体重児との 関連を表 1、2に示した。妊娠 16 週のよきの冷房環境の低出生体重児へのリスクは、専業主 婦を 1 とすると冷房環境に問題のある初産婦は8.2と有意なリスクの高まりがみられた。妊娠 22 週では、初産婦で泠房に問題のある妊婦か2.7と有意でないが高い值を示した。経産婦で は、いずれの週も冷房環境と有意な関連はみられなかった。有意な以上から、16 週で瞕場の 冷房環境に問題のある初産婦では、低出生体重児のリスクが高いことが示唆された。

表1. 妊娠 16 週の時の冷房環境と低出生体重児のオッズ比(OR)

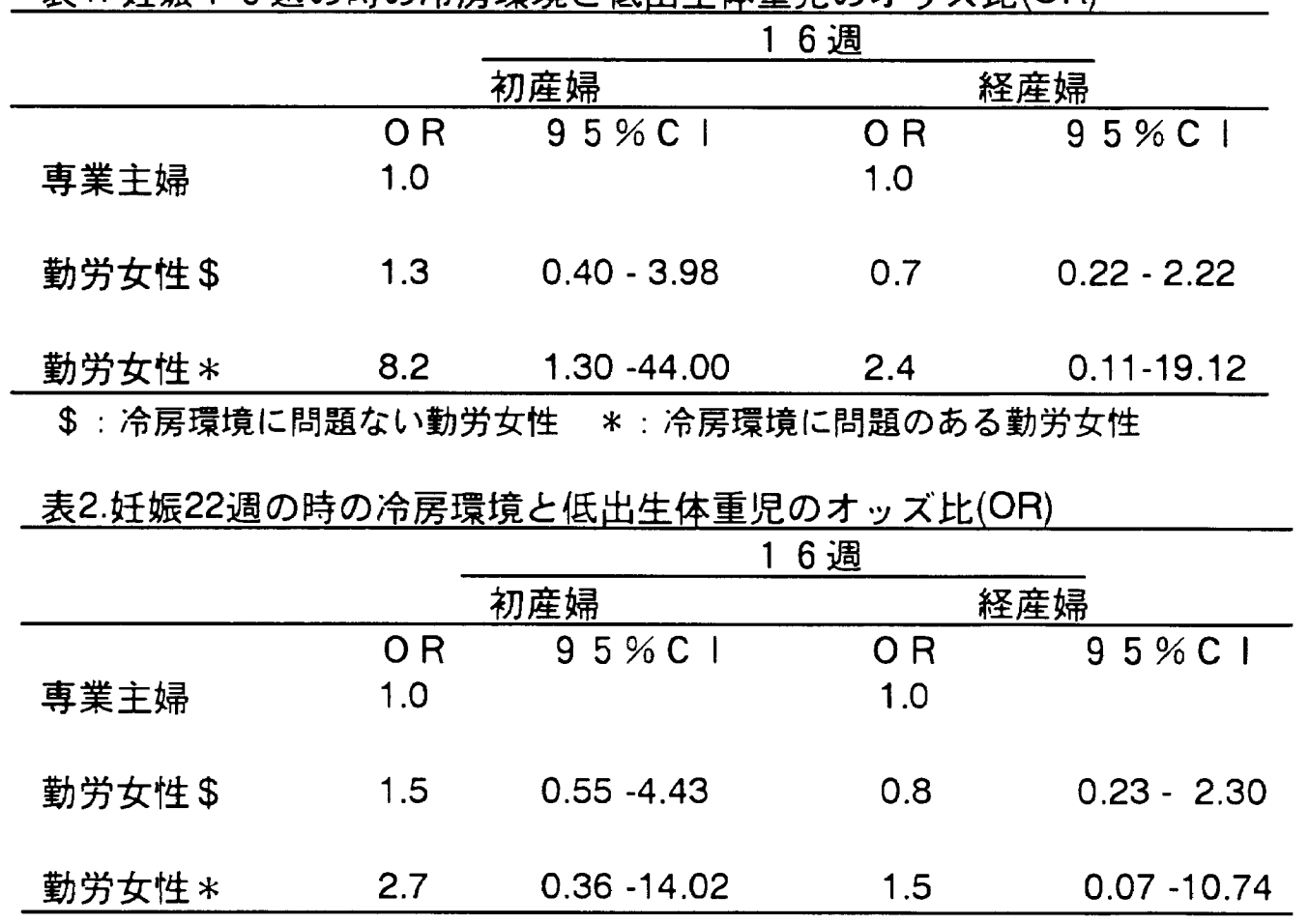

$\$:$ 冷房環境に問題ない勤労女性 $*$ : 冷房環境に問題のある勤労女性 